VOLUMINA JURASSICA, 2020, XVIII (1): 47-52

DOI: 10.7306/NJ.18.4

\title{
A review of the classification of Jurassic aspidoceratid ammonites - the Superfamily Aspidoceratoidea
}

\author{
Horacio PARENT ${ }^{1}$, Günter SCHWEIGERT ${ }^{2}$, Armin SCHERZINGER ${ }^{3}$
}

Key words: Superfamily Aspidoceratoidea, Aspidoceratidae, Epipeltoceratinae emended, Peltoceratidae, Gregoryceratinae nov. subfam.

\begin{abstract}
The aspidoceratid ammonites have been traditionally included in the superfamily Perisphinctoidea. However, the basis of this is unclear for they bear unique combinations of characters unknown in typical perisphinctoids: (1) the distinct laevaptychus, (2) stout shells with high growth rate of the whorl section area, (3) prominent ornamentation with tubercles, spines and strong growth lines running in parallel over strong ribs, (4) lack of constrictions, (5) short to very short bodychamber, and (6) sexual dimorphism characterized by miniaturized microconchs and small-sized macroconchs besides the larger ones, including changes of sex during ontogeny in many cases.

Considering the uniqueness of these characters we propose herein to raise the family Aspidoceratidae to the rank of a superfamily Aspidoceratoidea, ranging from the earliest Late Callovian to the Early Berriasian Jacobi Zone. The new superfamily includes two families, Aspidoceratidae (Aspidoceratinae, Euaspidoceratinae, Epipeltoceratinae and Hybonoticeratinae), and Peltoceratidae (Peltoceratinae and Gregoryceratinae nov. subfam.).

The highly differentiated features of the aspidoceratoids indicate that their life-histories were very different from those of the perisphinctoids; these ammonites show great promise for studies of developmental and evolutionary patterns and processes, and can be used for biostratigraphic-chronostratigraphic purposes and interprovincial correlations.
\end{abstract}

\section{INTRODUCTION}

The current systematics of the Jurassic Ammonitina is rather well-established, as recently reviewed by Howarth (2013, 2017) and Énay, Howarth (2019). The systematics of the Perisphinctoidea Steinmann, 1890 was essentially established by Schindewolf (1925), and through a vast number of papers, impossible to list all of them, many improvements based on new knowledge were gradually introduced, reflected in the major subsequent compilations, e.g., by Spath (1927-1933), Roman (1938), Basse (1952), Arkell et al. (1957), and Donovan et al. (1981).
The aspidoceratids have stood traditionally as one of the families of the Perisphinctoidea, however, on an unclear basis, perhaps because of their often cited origin as offshoots from the Perisphinctidae (Basse, 1952; Arkell et al., 1957; Donovan et al., 1981), and/or because of the ontogeny of their septal suture line (Schindewolf, 1966). The general origin of aspidoceratids from the Grossouvriinae in the late Middle Callovian can be assumed with little doubt (see Énay, Howarth, 2019, and references therein), but they developed very distinctive shell morphologies, ornamentations, evolutionary trends, life-histories, and modifications of sexual dimorphism.

\footnotetext{
${ }^{1}$ Laboratorio de Paleontología, IFG, Facultad de Ingeniería, Universidad Nacional de Rosario, Pellegrini 250, 2000 Rosario, Argentina; parent@fceia.unr.edu.ar.

${ }^{2}$ Staatliches Museum für Naturkunde, Rosenstein 1, 70191 Stuttgart, Germany; guenter.schweigert@smns-bw.de.

${ }^{3}$ Maurenstraße 26, 78194 Immendingen-Hattingen, Germany; Armin.Scherzinger@t-online.de.
} 

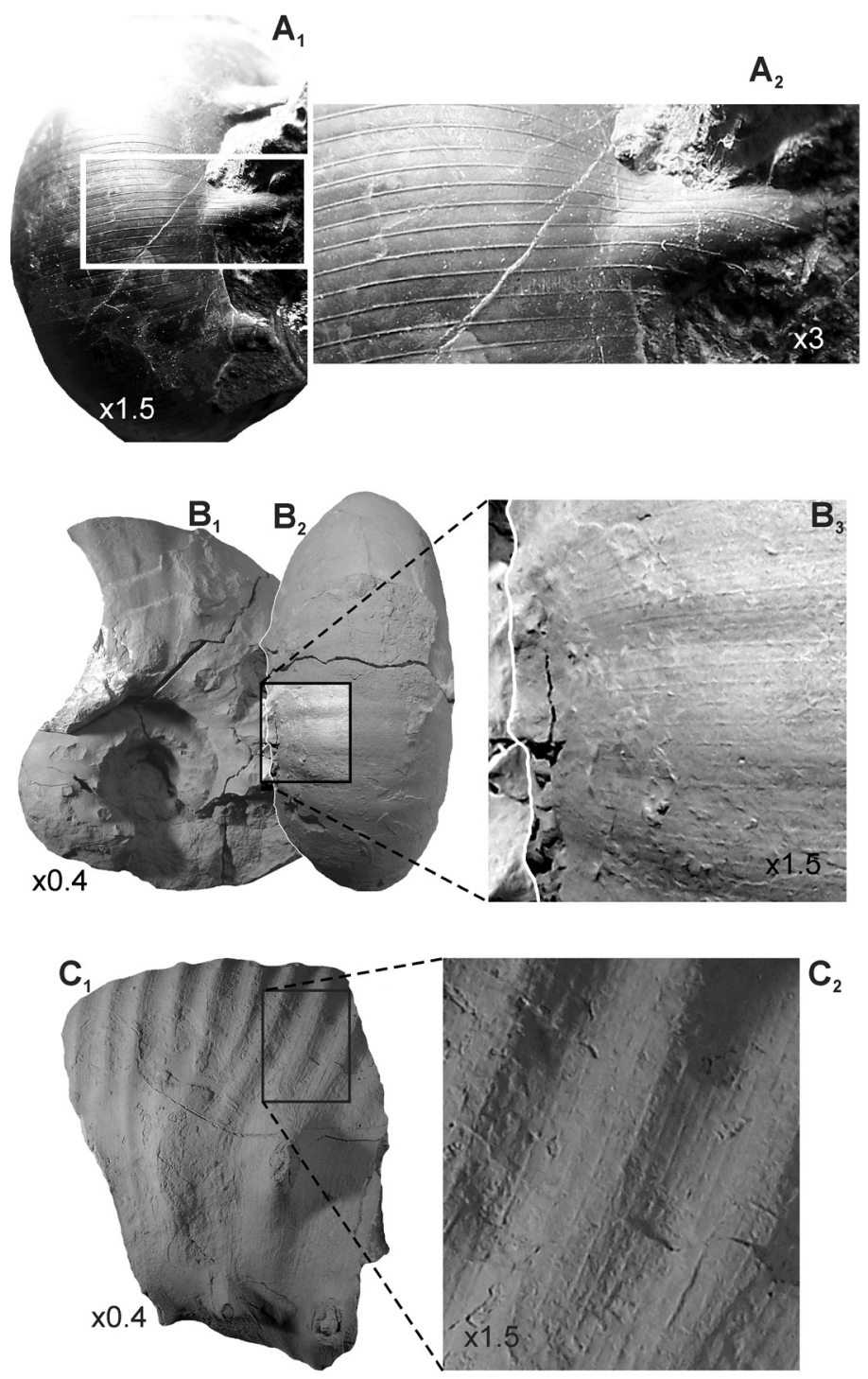

Fig. 1. Some ornamental details typical of aspidoceratoids

A - Aspidoceras euomphalum Steuer, 1897, Arroyo Cieneguita (Mendoza Province, Argentina), Internispinosum Zone (Andean upper Middle Tithonian). Juvenile macroconch phragmocone (Museo de Ciencias Naturales y Antropológicas "Juan Cornelio Moyano": MCNAM-24456/2), ventral views showing the growth lines evenly distributed, extended through the ventrolateral spines. The juvenile stages of the species bear no ribs, only growth lines. This specimen was formerly figured in Parent et al. (2011: fig. 36C) showing the structure of the spines; B - Aspidoceras euomphalum Steuer, 1897, Cerro Lotena (Neuquén Province, Argentina), Internispinosum Zone (Andean upper Middle Tithonian). Adult macroconch phragmocone (Laboratorio de Paleontología, Universidad Nacional de Rosario: LPB-1221), lateral $\left(B_{1}\right)$ and ventral $\left(B_{2}\right)$ views; $B_{3}$ : gross growth lines evenly distributed, running in parallel over wide, blunt ribs; C - Toulisphinctes cf. rafaeli (Oppel, 1863), Cerro Lotena, upper Proximus Zone (Andean Middle Tithonian). Fragmentary adult macroconch phragmocone (Laboratorio de Paleontología, Universidad Nacional de Rosario: LPB-1222); lateral views showing gross growth lines evenly distributed, running in parallel over gross ribs
In this paper we analyze the distinctive features of the aspidoceratids, concluding that this group of ammonites must be grouped as a separate superfamily.

\section{CHARACTERISTICS OF THE ASPIDOCERATIDS}

Throughout their evolution, the aspidoceratids have developed different combinations of unique characters unknown from any of the representatives of the other families included in the Perisphinctoidea, and many of them are unique even among the remaining Middle and Late Jurassic Ammonitina.

The most significant characters which make the aspidoceratids a group highly differentiated from typical perisphinctoids are:

1. Their very thick, strongly calcified, porous aptychus (lower mandible), the laevaptychus. This type of aptychus differs strongly from all the remaining types (see reviews by Lehmann, 1987; Parent et al., 2014; Parent, Westermann, 2016).

2. Most macroconchs (females) are more or less globose or stout, with different morphologies (from platycones to sphaerocones, see Arkell et al., 1957; Énay, Howarth, 2019), all of which show a high growth rate of the whorl section area.

3. Shells are in most cases heavily armoured; the sculpture includes floored and non-floored spines and/ or tubercles (bullate or spiny) (Checa, Martin-Ramos, 1989; Ifrim et al., 2018), and ribs often connecting the spines/tubercles. Shells are usually covered by strong growth lines running in parallel over gross ribs (Fig. 1). 4. Aspidoceratids lack any constrictions, which are otherwise characteristic and persistent for perisphinctoids.

5. The adult bodychamber is short to very short, with lengths $<180^{\circ}$, sometimes only close to $90^{\circ}$, both in microconchs (males) and especially in the macroconchs (females). In true perisphinctoids, the macroconchs have usually bodychamber lengths $\geq 270-360^{\circ}$.

6. Sexual dimorphism is characterized by miniaturized microconchs and the abundant occurrence of small-sized macroconchs (mesoconchs of Chandler, 2019) as well as occasional sexual change during ontogeny (see Parent et al., 2008; Scherzinger et al., 2018). In some aspidoceratid genera (e.g., Orthaspidoceras) corresponding microconchs have not been recorded; possibly the males became further reduced and lost their shell completely (Schweigert, 1997: 15, 16). 
Other characteristics which are very conspicuous in aspidoceratids and not common in other perisphinctoids:

a. A microphagous feeding style preying on small-sized planktonic organisms such as saccocomid crinoids (Keupp et al., 2016). This is known from their crop- or stomach contents preserved in specimens from lithographic limestones (Schweigert, Dietl, 1999), making them the baleen whales among Late Jurassic ammonites.

b. Aspidoceratids have successfully adapted to a wide range of biotopes and ecological settings, as reflected in their worldwide palaeogeographic distribution except for the Boreal/Polar regions.

c. Phyletic lineages tended to be long-lived, and many species occur morphologically almost unchanged in distant parts of the world, e.g., the Late Callovian Peltoceras retrospinatum Gérard \& Contaut, 1936 (Hillebrandt, Gröschke, 1995) and the Early Tithonian Pseudhimalayites subpretiosus (Uhlig, 1878; see Parent et al., 2011) in the Andes and in the western Tethys.

d. The septal suture line (whose subadult design and frilling are highly dependant upon the whorl section, Pictet, 1854: 669; Spath, 1919), has a wide and tabulated first saddle with a shallow mid-incision, the saddle usually covering radially one third to one half of the height of the flank of the shell (e.g., Basse, 1952: fig. 52: 22, 23; Schindewolf, 1966).

\section{THE SUPERFAMILY ASPIDOCERATOIDEA}

All or many of the above mentioned features are not known to be combined in any other group of the Perisphinctoidea. On this basis, it is herein proposed to raise the family Aspidoceratidae Zittel, 1895 to the rank of a superfamily, with the following arrangement:

\section{Superfamily Aspidoceratoidea Zittel, 1895}

\section{Family Aspidoceratidae Zittel, 1895}

Subfamily Aspidoceratinae Zittel, 1895

Subfamily Euaspidoceratinae Spath, 1931

Subfamily Epipeltoceratinae Donovan et al., 1981

Subfamily Hybonoceratinae Olóriz, 1978

\section{Family Peltoceratidae Spath, 1924}

Subfamily Peltoceratinae Spath, 1924

Subfamily Gregoryceratinae nov. Diagnosis. Smooth or ribbed flanks in the inner whorls; outer whorls with strongly angular and rursiradiate ribbing; subtrapezoidal whorl section with flattened venter and concave flanks in the adult stage. Genera included: Gregoryceras Spath, 1924, Pseudogregoryceras Jeannet, 1951.

Remarks. The Aspidoceratoidea includes two main lineages, whose earliest representatives belong to Euaspidoceras Spath, 1931 (Aspidoceratidae) and Peltoceras Waagen, 1871 (Peltoceratidae), respectively. The total stratigraphic range of this superfamily is rather well established. The earliest known forms appear during the earliest Late Callovian (Bonnot et al., 2005). The latest representatives are globose Physodoceras (see Wierzbowski, Remane, 1992: pl. 2: 7) and evolute "Aspidoceras" taverai Checa (1985: pl. 19: 3, 4) of the Early Berriasian Jacobi Zone.

For the distribution of genera within each family see Énay, Howarth, 2019. Euaspidoceras seems to have been the root of the other main lineages of the Aspidoceratinae (Clambites Rollier, 1922, Physodoceras Hyatt, 1900, and Aspidoceras Zittel, 1868) in the Bimammatum Zone (see e.g., Schweigert, 1997; Schweigert, Callomon, 1997; Énay, Howarth, 2019), whose earliest representatives are known from the Submediterranean Province and the western Tethys.

Epipeltoceratinae is emended from its original definition to (1) include the genera Clambites, Epipeltoceras Spath, 1924, and Amoebopeltoceras Schweigert, 1995, and (2) to exclude the genera Klematosphinctes Buckman, 1922 and Mirosphinctes Schindewolf, 1926, the latter two represent microconchs of Euaspidoceras (Euaspidoceratinae). The continued use of the Epipeltoceratinae is preferred instead of introducing a new subfamily based on Clambites, a genus which is morphologically still close to its euaspidoceratin rootstock, whereas the corresponding microconchs are highly diagnostic.

Gregoryceratinae nov. subfam. is characterized by total reduction of microconchs; they are only represented as fossils by meso- and macroconchs. Stratigraphic range (Schweigert, Ebel, 1999; Bert, 2004; Énay, Howarth, 2019): Cordatum Zone (Lower Oxfordian) to Bimammatum Zone (base of the Kimmeridgian sensu Wierzbowski et al., 2016).

\section{DISCUSSION AND CONCLUSION}

Engeser, Keupp (2002: 88) suggested the Aspidoceratidae could be separated from the Perisphinctoidea, based on a supposed condition of "well defined monophyletic unit".

The highly differentiated features of the aspidoceratoids indicate that their life-histories were very different from those of the perisphinctoids. This could be discussed at length, but there is room here just for a short set of speculations. A direct consequence of the high growth rates of the whorl section area seems to be the fact that the adult macro- 
and microconchs have comparatively lower numbers of whorls than most, if not all the perisphinctoids, i.e. either they grew up rapidly, or (less probably, see Hewitt et al., 1993; Bucher et al., 1996) their life-span was shorter. Sexual change as well as accelerated sexual maturation resulting in small-sized females, so-called "mesoconchs" (Chandler, 2019), has been demonstrated for some Late Jurassic aspidoceratids (Parent et al., 2008; Scherzinger et al., 2018). The great variety of morphologies known in aspidoceratoids seems to indicate that their genetic programs were able to evolve fast morphologic changes, enabling adaptations to a wide spectrum of environmental conditions.

The group of the aspidoceratid ammonites should be arranged into the rank of superfamily since they are significantly different from all other perisphinctoids. The members of the Aspidoceratoidea show great potential for studies of the developmental and evolutionary patterns and processes in ammonites, and can be used for biostratigraphic-chronostratigraphic purposes and interprovincial correlations.

Acknowledgements. Raymond Énay (Université Claude Bernard-Lyon 1, France), Mike K. Howarth (The Natural History Museum London, U.K.), Desmond T. Donovan (†, University College London, U.K.) and Antonio G. Checa (Universidad de Granada, Spain) kindly provided us with relevant literature. The journal referees Raymond Énay (Université Claude Bernard-Lyon 1, France) and István Főzy (Hungarian Natural History Museum, Hungary) made valuable reviews, and the editor Pawel Zawada helped in improvement of the manuscript.

\section{REFERENCES}

ARKELL W.J., KUMMEL B., WRIGHT C.W., 1957 - Mesozoic Ammonoidea. In: Treatise on Invertebrate Paleontology: Part 1, Mollusca 4: L80-L437 (Ed. R.C. Moore). Kansas University Press, Kansas.

BASSE É., 1952 - Sous-classe des Ammonoidea. In: Traité de Paléontologie (Ed. J. Piveteau): 522-555. Masson et Cie, Paris.

BERT D., 2004 - Révision, études systématique el évolution du genre Gregoryceras Spath, 1924 (Ammonoidea, Oxfordien). Annales du Museum d'Histoire Naturelle de Nice, 19: 1-184.

BONNOT A., BOURSICOT P.-Y., FERCHAUD P., 2005 - Peltoceras marysae, une nouvelle espèce de Peltoceratinae (Ammonitina, Aspidoceratidae) dans l'horizon à Leckenbyi (Callovien supérieur, zone à Athleta) de Montreuil-Bellay (Maine-et-Loire, France). Revue de Paléobiologie, 24, 1: 75-95.

BUCHER H., LANDMAN N.H., KLOFAK S.M., GUEX J., 1996 - Mode and rate of growth in ammonoids. In: Ammonoid Paleobiology (Eds. N.H. Landman et al.). Topics in Geobiology, 13: $407-461$.

BUCKMAN S.S., 1922 - Type ammonites, vol. 4, parts 31-37. Wheldon \& Wesley. London.
CHANDLER R.B., 2019 - Two new stephanoceratid ammonites from the Aalenian-lower Bajocian (Middle Jurassic, Dorset, UK) and their phylogenetic significance. Proceedings of the Geologists' Association, 130: 307-325.

CHECA A., 1985 - Los Aspidoceratiformes en Europa (Ammonitina, fam. Aspidoceratidae, subfamilias Aspidoceratinae y Physodoceratinae). Facultad de Ciencias, Departamento de Paleontologia y Geologia general. Thesis doctoral, Universidad de Granada. 1-27, 413 p.

CHECA A., MARTIN-RAMOS D., 1989 - Growth and function of spines in the Jurassic ammonite Aspidoceras. Palaeontology, 32: $645-655$.

DONOVAN D.T., CALLOMON J.H., HOWARTH M.K., 1981 Classification of the Jurassic Ammonitina. In: The Ammonoidea (Eds. M.R. House, J.R. Senior). The Systematics Association, Special Volume 18: 101-155. Academic Press, London.

ÉNAY R., HOWARTH M.K., 2019 - Systematic descriptions of the Perisphinctoidea. Part L, revised, vol. 3B, chapter 7. Treatise Online, 120: 1-184.

ENGESER T., KEUPP H., 2002 - Phylogeny of the aptychi-possessing Neoammonoidea (Aptychophora nov., Cephalopoda). Lethaia, 34: 79-96.

GÉRARD C., CONTAUT H., 1936 - Les ammonites de la zone à Peltoceras athleta du Centre-Ouest de la France. Mémoire de la Societé Géologique de France, 29: 1-79.

HEWITT R.A., WESTERMANN G.E.G., CHECA A., 1993 Growth rates of ammonites estimated from Aptychi. Geobios M.S., 15: 203-208.

HILLEBRANDT A.V., GRÖSCHKE M., 1995 - Ammoniten aus dem Callovium/Oxfordium Grenzbereich von Nordchile. Berliner geowissenschaftliche Abhandlungen, A169: 1-40.

HOWARTH M.K., 2013 - Psiloceratoidea, Eodoceratoidea, Hildoceratoidea. Part L, revised, vol. 3B, chapter 4. Treatise Online, 57: 1-139.

HOWARTH M.K., 2017 - Systematic descriptions of the Stephanoceratoidea and Spiroceratoidea. Part L, revised, vol. 3B, chapter 6. Treatise Online, 84: 1-101.

HYATT A., 1900 - Cephalopoda. In: Textbook of Palaeontology, 1st English edition (Ed. K.A. v. Zittel; transl. C.R. Eastman): 502-592.

IFRIM C., BENGTSON P., SCHWEIGERT G., 2018 - Growth and function of spines in Jurassic and Cretaceous ammonites. Cretaceous Research, 88: 62-78.

JEANNET A., 1951 - Stratigraphie und Palaeontologie des oolithischen Eisenerzlagers von Herznach und seiner Umgebung. Beit räge zur Geologie der Schweiz, Geotechnische Serie, 13, 5: 1-240.

KEUPP H., HOFFMANN R., STEVENS K., ALBERSDÖRFER R., 2016 - Key innovations in ammonoids: the multicuspidate radula and the calcified aptychus. Palaeontology, 59, 6: 775-791.

LEHMANN U., 1987 - Ammoniten. Ihr Leben und ihre Umwelt. Enke-Verlag, Stuttgart.

OLÓRIZ F., 1978 - Kimmeridgiense-Titonico inferior en el sector central de las Cordilleras Béticas (Zona Subbética). Paleontologia. Bioestratigrafia. Thesis Doctorales, Universidad de Granada. $184,1-758$.

OPPEL A., 1862-1863 - III. Ueber jurassische Cephalopoden. Palaeontologische Mittheilungen aus dem Museum des koeniglich Bayerischen Staates, 1: 127-262. 
PARENT H., WESTERMANN G.E.G., 2016 - Jurassic ammonite aptychi: functions and evolutionary implications. Swiss Journal of Palaeontology, 135: 101-108.

PARENT H., SCHERZINGER A., SCHWEIGERT G., 2008 Sexual phenomena in Late Jurassic Aspidoceratidae. Dimorphic correspondence between Physodoceras hermanni (Berckhemer) and Sutneria subeumela Schneid, and first record of possible hermaphroditism. Palaeodiversity, 1: 181-187.

PARENT H., SCHERZINGER A., SCHWEIGERT G., 2011 - The Tithonian-Berriasian ammonite fauna and stratigraphy of Arroyo Cieneguita, Mendoza, Argentina. Boletín del Instituto de Fisiografia y Geología, 79-81: 21-94.

PARENT H., WESTERMANN G.E.G., CHAMBERLAIN J.A., 2014 - Ammonite aptychi: functions and role in propulsion. Geobios, 47, 1/2: 45-55.

PICTET F.-J., 1854 - Traité de Paléontologie. vol. 2. J.-B. Baillière, Paris.

ROLLIER H.L., 1922 - Phylogénie des Ammonoïdes. Eclogae Geologicae Helvetiae, 17: 358-360.

ROMAN F., 1938 - Les Ammonites Jurassiques et Crétacées. Masson, Paris.

SCHERZINGER A., PARENT H., SCHWEIGERT G., 2018 A new species of the ammonite genus Physodoceras Hyatt (Aspidoceratidae) from the Hybonotum Zone (Lower Tithonian) of Southern Germany, with comments on the phylogeny of the genus. Boletín del Instituto de Fisiografia y Geología, 88: 11-24.

SCHINDEWOLF O.H., 1925 - Entwurf einer Systematik der Perisphincten. Neues Jahrbuch für Mineralogie, Geologie und Paläontologie, Beilage-Bände, 52, B: 309-343.

SCHINDEWOLF O.H., 1926 - Zur Systematik der Perisphincten. Neues Jahrbuch für Mineralogie, Geologie und Paläontologie, Beilage Band, 55, B: 497-517.

SCHINDEWOLF O.H., 1966 - Studien zur Stammesgeschichte der Ammoniten. Lieferung V. Abhandlungen der Akademie der Wissenschaften und der Literatur Mainz, mathematisch-naturwissenschaftliche Klasse, 1966, 3: 326-454.

SCHWEIGERT G., 1995 - Amoebopeltoceras n. g., eine neue Ammoniten-Gattung aus dem Oberjura (Ober-Oxfordium bis Unter-Kimmeridgium) von Süddeutschland und Spanien. Stuttgarter Beiträge zur Naturkunde, Serie B, 227: 1-10.

SCHWEIGERT G., 1997 - Die Ammonitengattungen Simocosmoceras Spath und Pseudhimalayites Spath (Aspidoceratidae) im süddeutschen Oberjura. Stuttgarter Beiträge zur Naturkunde, Serie B, 246: 1-29.

SCHWEIGERT G., CALLOMON J.H., 1997 - Der bauhini-Faunenhorizont und seine Bedeutung fur die Korrelation zwischen tethyalem und subborealem Oberjura. Stuttgarter Beiträge zur Naturkunde, Serie B, 247: 1-69.
SCHWEIGERT G., DIETL G., 1999 - Zur Erhaltung und Einbettung von Ammoniten im Nusplinger Plattenkalk (Oberjura, Südwestdeutschland). Stuttgarter Beiträge zur Naturkunde, Serie $B, 272$ : $1-31$.

SCHWEIGERT G., EBEL K., 1999 - Der stratigraphisch jüngste Nachweis der Ammonitengattung Gregoryceras (Oberjura, Bimammatum-Zone). Neues Jahrbuch für Geologie und Paläontologie, Monatshefte, 1999: 95-100.

SPATH L.F., 1919 - Notes on ammonites. The Geological Magazine, 56: 27-35.

SPATH L.F., 1924 - On the Blake Collection of Ammonites from Kachh, India. Palaeontologica Indica, New series 9, Memoir 1: 1-29.

SPATH L.F., 1927-1933 - Revision of the Jurassic cephalopod fauna of Kachh (Cutch). Palaeontologica Indica, New series 9 , 2: 1-945.

STEINMANN G., 1890 - Cephalopoda. In: Elemente der Paläontologie (Eds. G. Steinmann, L. Döderlein): 344-475. Leipzig, Engelmann.

STEUER A., 1897 - Argentinische Jura-Ablagerungen. Ein Beitrag zur Kenntnis der Geologie und Paläontologie der argentinischen Anden. Palaeontologische Abhandlungen (N.F. 3), 7: 129-222.

UHLIG V., 1878 - Beiträge zur Kenntnis der Jura-Formation in den Karpatischen Klippen. Jahrbuch der kaiserlich-königlichen Geologischen Reichsanstalt, 28: 641-658.

WAAGEN W.H., 1871 - Abstract of results of examination of the ammonite-fauna of Kutch, with remarks on their distribution among the beds, and probable age. Records of the Geological Survey of India, 4: 89-101.

WIERZBOWSKI A., REMANE J., 1992 - The ammonite and calpionellid stratigraphy of the Berriasian and lowermost Valanginian in the Pieniny Klippen Belt (Carpathians, Poland). Eclogae Geologicae Helvetiae, 85: 871-891.

WIERZBOWSKI A., ATROPS F., GRABOWSKI J., HOUNSLOW M., MATYJA B.A., OLÓRIZ F., PAGE K., PARENT H., ROGOV M.A., SCHWEIGERT G., VILLASEÑOR A.B., WIERZBOWSKI H., WRIGHT J.K., 2016 - Towards a consistent Oxfordian/Kimmeridgian global boundary: current state of knowledge. Volumina Jurassica, 14: 15-50.

ZITTEL K.A., 1868 - Palaeontologische Studien über die Grenzschichten der Jura und Kreide-Formation im Gebiete der Karpathen, Alpen und Apenninnen. 1. Die Cephalopoden der Stramberger Schichten. Palaeontologische Mittheilungen aus dem Museum des koeniglich Bayerischen Staates, 2: 1-118.

ZITTEL K.A., 1895 - Grundzüge der Paläontologie. R. Oldenbourg, Munich \& Leipzig. 
